J. Perinat. Med. 13 (1985) 195

\title{
The influence of the progress of labor on the reliability of the transcutaneous $\mathrm{Pco}_{2}$ of the fetus
}

\author{
S. Schmidt, K. Langner, J. Gesche, J. W. Dudenhausen, E. Saling \\ Institute of Perinatal Medicine, The Free University of Berlin \\ Department of Obstetrics, Berlin-Neukölln
}

\section{Introduction}

With transcutaneous carbon dioxide measurement $\left(\mathrm{tc} \mathrm{PcO}_{2}\right)$ now routine in the field of neonatology, this method is currently being utilized in the fields of anesthesia and obstetrics $[4,5,6]$. Whereas in neonatology and anesthesia the measurements are influenced mainly by static factors, in obstetrics the measurements are influenced by a dynamic process, the progress of labor.

As has been demonstrated previously for tc $\mathrm{Po}_{2}$, the patterns of these measurements are considerably influenced by the progress of labor $[2,3,8]$. To prove that this principle is also valid for $\mathrm{tc}^{\mathrm{PCO}} 2$ we measured the transcutaneous $\mathrm{PcO}_{2}$ and the $\mathrm{PcO}_{2}$ in blood samples of 105 fetuses during labor [9].

\section{Materials and methods}

In addition to cardiotocography continuous tc $\mathrm{PcO}_{2}$ measurement was performed on 105 fetuses during labor. The cumulative recording time was 312 hours and 20 minutes. The shortest recording time was 30 minutes and the longest tc $\mathrm{PcO}_{2}$ measurement lasted for 10 hours and 15 minutes. The average recording time was 3 hours and 12 minutes. All the fetuses were born from the vertex presentation. All newborns were in a vigorous state (Apgar $\geq 7$ ). In 21 cases there were umbilical artery $\mathrm{pH}$-values between 7.24 and 7.20 ; in 5 cases the $\mathrm{pH}$ value was $\leq 7.19$.

Forty-six babies were delivered spontaneously, 39 by vacuum extraction, 10 by modified forceps [10] and 10 by cesarean section. Sixtynine of the women were nulliparas, 18 primiparas and 18 multiparas.

A modified SEVERINGHAUs electrode was used for all the measurements. This electrode incorporates a heating element, a temperature sensor, the glass $\mathrm{pH}$-electrode and the reference electrode [12]. The sterilization of the electrode was done in formaldehyde steam under pressure procedure at $60^{\circ} \mathrm{C}$. A two-point calibration of the tc $\mathrm{PcO}_{2}$ electrode with $5 \%$ and $10 \%$ carbondioxide gas with 33 and 66 torr respectively was performed. This corresponds to a drop in the $\mathrm{PcO}_{2}$ levels measured transcutaneously of about $13 \%$ and to an adjustment to the blood gas level. The calibration and measuring temperature was $39^{\circ} \mathrm{C}$. In order to trace the electrode drift during the measuring procedure a control was performed with $10 \%$ carbon dioxide gas at the completion of the measurements. The maximal drift noted was $8 \%$; and the drift was usually below $2 \%$.

The time required to reach the steady-state for tc $\mathrm{PcO}_{2}$ in the middle of 105 measurements was $18.4 \pm 3.5$ minutes [11]. 
Of the 116 attempts made, the electrode application was unsuccessful in 11 . In 6 cases the electrode became completely or partially dislodged after application. In 5 cases there was a mechanical compression of the electrode between the fetal head and the pelvic wall; this was verified by the tc $\mathrm{Pco}_{2}$ recording, the flow and vaginal examination. In 46 cases the recording was continued up to the baby's delivery.

Blood gas analyses were performed alternatively on a Corning 175 or RADIOMETER $\mathrm{ABL}_{2}$ blood gas analyzer. For evaluation, data were fed into a CYBER 70 (Control Data) and were evaluated with the Statistical Package for Social Science (SPSS) of Northwestern University. :The linear correlation coefficient, the slope, the intercept and the significance level were calculated for comparison of transcutaneously measured $\mathrm{PcO}_{2}$ levels to blood $\mathrm{PcO}_{2}$ levels (fetal capillary or peripheral and umbilical artery).

\section{Results}

The comparison of the transcutaenous $\mathrm{Pco}_{2}$ measurements with $\mathrm{PcO}_{2}$ values obtained from fetal blood analyses showed a good correlation with a slope of 0.91 and an intercept of $+7,4$. The correlation coefficient (r) was 0.74 . The significance level was $p<0.001$. In Fig. 1 the influence of the caput succedaneum on the correlation between tc $\mathrm{PcO}_{2}$ and peripheral

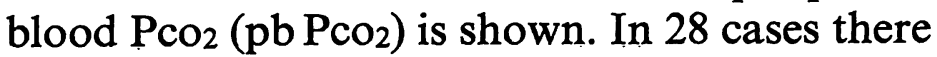
was no caput succedaneum when a fetal blood analysis was being performed simultaneously with the transcutaneous $\mathrm{Pco}_{2}$ measurement.

The slope was 1.1 , the intercept 2.3 , the correlation coefficient 0.79 . The significance level was $\mathrm{p}<0.001$ (Fig. 1 a).

In 86 cases before fetal blood sampling a caput succedaneum was palpated during the vaginal examination. There was a slope of 0.85 and an intercept of $+10,4$. The correlation coefficient was 0.72 , the significance $<0.001$ (Fig. $1 \mathrm{~b}$ ).

In order to analyze the influence of the propulsion of the fetal head during labor on the correlation between tc $\mathrm{PcO}_{2}$ and $\mathrm{pb} \mathrm{Pco}_{2}$ levels, we differentiated the single pairs of levels according to the position of the fetal head. During 12 fetal blood analyses the fetal head was in the pelvic inlet. The presenting part was either above or in the interspinal plane. There

a)

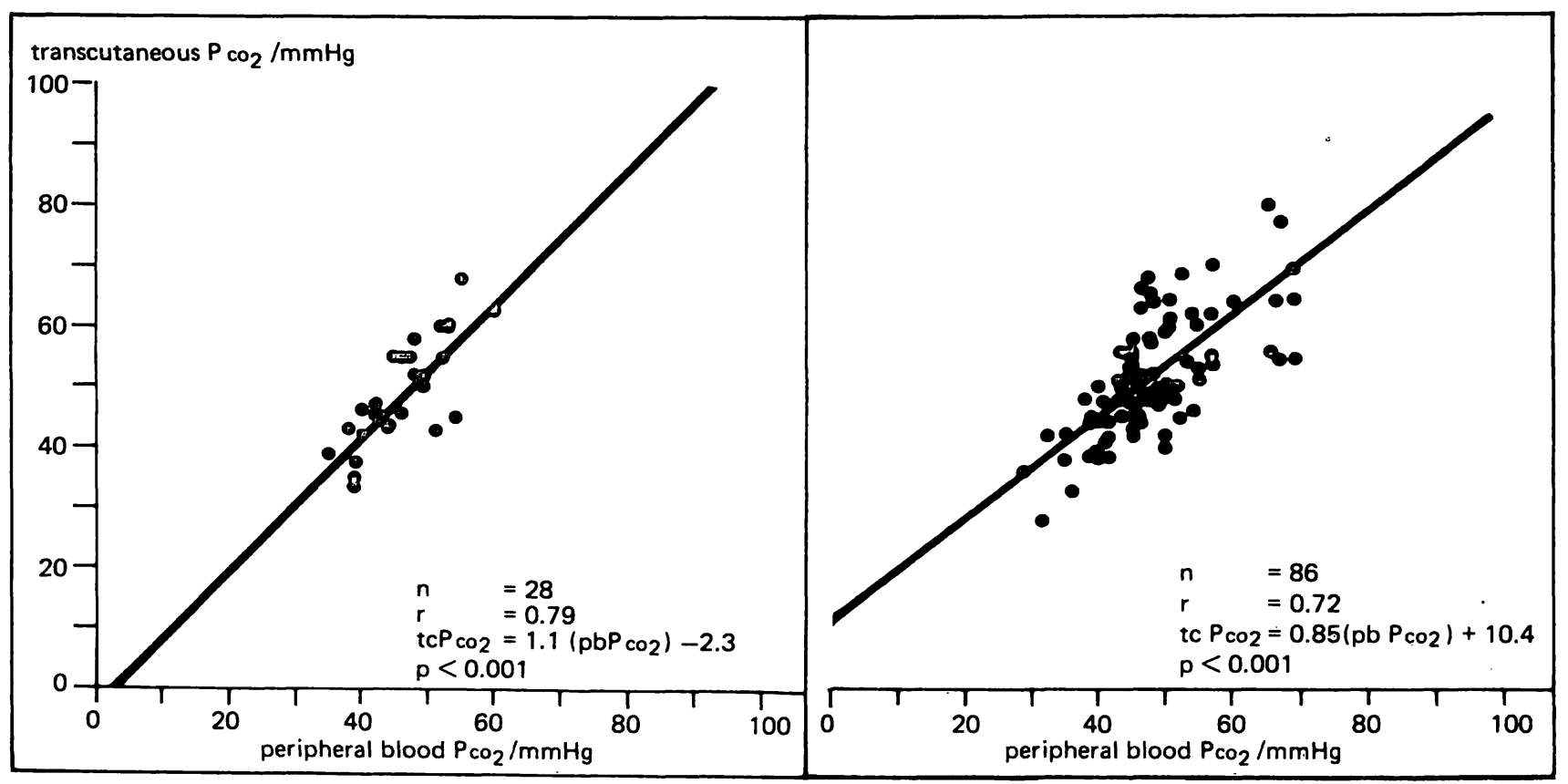

Fig. 1a. Correlation between transcutaneously measured $\mathrm{Pco}_{2}$ (tc $\mathrm{PcO}_{2}$ ) and $\mathrm{Pco}_{2}$ of the peripheral blood (pb Pcon) in cases where no caput succedaneum has been present.

Fig. 1 b. Correlation between tc $\mathrm{PcO}_{2}$ and $\mathrm{pbPco}_{2}$ in cases with caput succedaneum. 


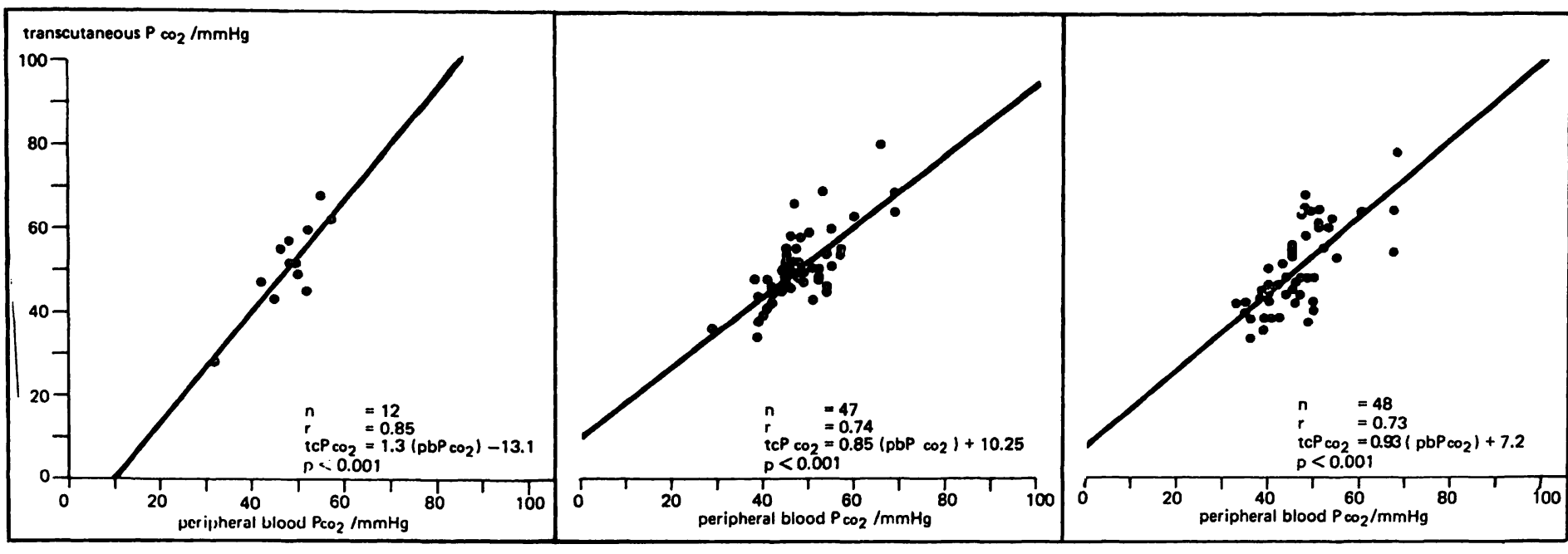

a)

b)

c)

Fig. 2. Correlation between $\mathrm{tc} \mathrm{PcO}_{2}$ and $\mathrm{pbPCO}_{2}$ dependent on the progress of labor;

a) fetal head in pelvic inlet: presenting part above or in interspinal plane;

b) fetal head in pelvic inlet: presenting part below the interspinal plane;

c) fetal head in midpelvic plane.

was a slope of 1.3 and an intercept of -13.1 . The correlation coefficient amounted to 0.85 , the significance was $\mathrm{p}<0.001$ (Fig. 2a).

In a group of 47 fetal blood samples the presenting part was 1 or $2 \mathrm{cms}$ below the interspinal plane. The slope in this range amounted to 0.85 , the intercept was 10.25 , the correlation coefficient amounted to 0.74 and the sig-

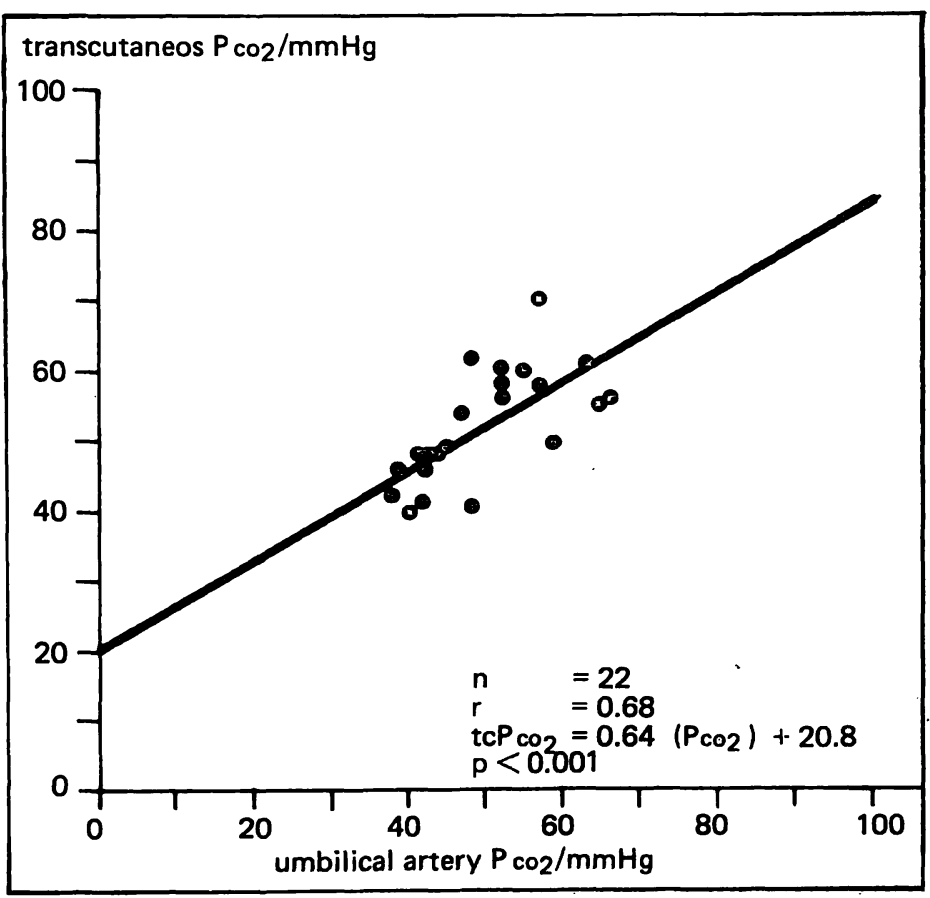

Fig. 3. Correlation between tc $\mathrm{PcO}_{2}$ and $\mathrm{PcO}_{2}$ measured in the umbilical artery. nificance level was $\mathrm{p}<0.001$ (Fig. 2b). During 48 fetal blood samples the fetal head was in the midpelvic plane, the slope was 0.93 , the intercept 7.2 , the correlation coefficient 0.73 and the significance level $\mathrm{p}<0.001$ (Fig. 2c).

In order to compare the levels of transcutaneously measured $\mathrm{PcO}_{2}$ with the central blood levels of the fetus during expulsion, the correlation between $\mathrm{tc}^{\mathrm{PCO}} 2$ and the blood $\mathrm{PcO}_{2}$ levels from the umbilical artery was calculated. This was possible in 22 cases where the tc $\mathrm{Pco}_{2}$ levels were recorded up to the babies delivery, and blood samples were taken from the umbilical artery for blood gas analysis. The slope in this case was 0.64 , the intercept 20.8 , the correlation coefficient 0.68 , and the significance $\mathrm{p}<0.001$ (Fig. 3).

\section{Discussion}

Transcutaneous $\mathrm{Pco}_{2}$ measurement in the fetus during labor is a new method of intrapartum fetal monitoring. Before becoming routinely used for clinical surveillance of the fetus during labor, the margin of error and the avoidance of failure of this new method must be fully explored. Factors that influence the validity of the transcutaneous $\mathrm{Pco}_{2}$ measurements must be taken into consideration. This will depend on 
those factors that basically influence a transcutaneous measurement of blood gases including the partial pressure in central blood, the thickness of the epidermis, the area of the transcutaneous measurement, and the degree of dilatation of the vessels within the range of measurement [7]. When interpreting the transcutaneously measured values of the carbondioxide partial pressure during labor, consideration should be given to the peculiarities of the physiology of fetal circulation and their influence on the partial pressure relationships within the measuring range, and in particular those features of circulatory autoregulation in the area of the cranial perfusion of the fetus: as well as the peculiarities i within the area of the capillary layer of the fetal scalp [1].

In addition to these considerations we know from experience in fetal transcutaneous oxygen measurements during labor, that the progress of labor can influence the data obtained transcutaneously $[2,3,8]$.

We tried to determine the influence of those factors of birth that would most likely diminish the reliability of the transcutaneous recording, namely the propulsion of the baby and the development of a caput succedaneum. With development of a capuit succedaneum correlation coefficients of the comparison between the partial pressure of carbon dioxide registered transcutaneously and measured in the fetal blood were considerably lowered. Such effect on the reliability of the transcutaneous measurement might be partly explained with changes in the peripheral circulation and additionally an increase of the distance between the measuring chamber and the fetal blood vessels.

Furthermore the propulsion of the fetal head is shown to have an influence on the reliability of the tc $\mathrm{PcO}_{2}$ measurement. This result of our analysis may be explained by compression phenomena of the electrode occurring in some cases between the fetal head and the pelvic wall. Such a phenomenon seems to become more likely when the fetal head proceeds below the interspinal plane.

In conclusion it can be said that changes in the correlation coefficients reflect the influence of the progress of labor. Nevertheless our analysis has proved that, in spite of the influence of the phenomena examined due to the progress of labor, there still remains a statistically significant conformity between carbon dioxide levels measured transcutaneously and the levels in the fetal blood.

\section{Summary}

Transcutaneous $\mathrm{Pco}_{2}$ measurements were performed on 105 fetuses during labor.

A modified SEVERINGHAUS electrode was calibrated with $5 \%$ and $10 \%$ carbon-dioxide gas at 33 and 66 torr. This corresponds to a drop in the $\mathrm{PcO}_{2}$ levels measured transcutaneously of about $13 \%$ and to an adjustment to the blood gas level.

The levels measured transcutaneously were compared with data compiled from the fetal blood analysis and values of blood gas analysis from the umbilical artery immediately after delivery. The object of the study was to find out to what extent the progress of labor influences the conformity between the $\mathrm{PcO}_{2}$ levels measured transcutaneously and measured in blood.

Comparing the data of the transcutaneous measurement $(\mathrm{pbPco})$ with the $\mathrm{pbPcO}_{2}$ of the peripheral blood $\left(\mathrm{pb} \mathrm{PcO}_{2}\right)$ in cases without a caput succedaneum, we

found a correlation coefficient of $\mathrm{r}=0.79$ and a slope of 1.1. On the other hand with the development of a caput succedaneum the correlation coefficient was lowered to $\mathrm{r}=0.72$ and the slope to 0.85 .

An influence of the propulsion of the fetal head in the birth canal on the accurary of the transcutaneous measurement was also obvious. When the position of the fetal head was either above or in the interspinal plane, the correlation coefficient amounted to $r=0.85$. With the progression below the interspinal plane, the correlation coefficient was clearly lowered.

While our results show a good overall conformity between $\mathrm{PcO}_{2}$ levels measured transcutaneously and those from peripheral blood, our analysis shows also to what extent the conformity can be influenced both by the existence of a caput succedaneum and by the propulsion of the presenting part. Keywords: Caput succedaneum, fetal blood analysis (FBA), fetal monitoring, progress of labor, transcutaneous
Pco 2 . 


\section{Zusammenfassung}

Einfluß des Geburtsfortschrittes auf die Zuverlässigkeit der transkutanten Messung des Kohlendioxydpartialdrukkes beim Feten

Bei 105 Feten wurde während der Geburt eine transkutane Messung des Kohlendioxydpartialdruckes (tc $\mathrm{PCO}_{2}$ durchgeführt. Die für die Messung verwendete modifizierte SEveringhaus-Elektrode wurde mit $5 \%$ und $10 \%$ igen $\mathrm{CO}_{2}$-Gas bei 33 bzw. $66 \mathrm{~mm} \mathrm{Hg}$ kalibriert. Dieses entspricht einer Verminderung der transkutan erhobenen Meßdaten um 13\% und somit einer Angleichung an das Blutgasniveau. Die tc $\mathrm{PcO}_{2}$-Werte wurden mit dem Kohlendioxydpartialdruck im Blut des Feten verglichen. Gegenstand der Untersuchung war die Frage, in welchem Umfang der Geburtsfortschritt die $\mathrm{Zu}$ verlässigkeit der transkutan erhobenen Meßwerte beeinflußt.

In den Fällen, bei denen sich während der Messung keine Kopfgeschwulst ausgebildet hatte, fanden wir bei dem Vergleich mit dem $\mathrm{PcO}_{2}$ der Fetalblutanalyse einen Korrelationskoeffizienten von $\mathrm{r}=0,79$ und eine Stei- gung der Korrelationsgeraden von 1,1. Nach Ausbildung einer Kopfgeschwulst hingegen war der Korrelationskoeffizient auf $r=0,72$ und die Steigung der Korrelationsgeraden auf 0,85 vermindert.

Auch das Tiefertreten des Kopfes hatte einen deutlichen Einfluß auf das Maß der Übereinstimmung zwischen transkutan und blutig gemessenen $\mathrm{PcO}_{2}$-Werten. Für den Fall, daß der Kopf entweder in oder oberhalb der Interspinalebene war, lag der Korrelationskoeffizient bei 0,85 . Unterhalb der Interspinalebene war der Korrelationskoeffizient deutlich niedriger. Während wir insgesamt eine gute Übereinstimmung zwischen den Meßdaten der tc PcO2-Registrierung mit den $\mathrm{PcO}_{2}$-Werten im fetalen Blut fanden, stellten wir einen deutlichen Einfluß des Geburtsfortschrittes auf die tc $\mathrm{Pco}_{2}$-Messung fest. Sowohl mit dem Tiefertreten des Kopfes unter die Interspinalebene als auch mit dem Auftreten einer Geburtsgeschwulst war eine geringere Meßgenauigkeit der transkutanen Messung verbunden.

Schlüsselwörter: Fetalblutanalyse, fetale Überwachung, Geburtsfortschritt, Geburtsgeschwulst, transkutaner Kohlendioxydpartialdruck.

\section{Résumé}

Influence de l'évolution du travail sur la fiabilité de la Pco2 transcutanée foetale

On a mesuré la $\mathrm{Pco}_{2}$ transcutanée chez 105 fœtus au cours du travail.

Une électrode de SEVERINGHaUs modifiée a été calibrée avec du dioxyde de carbone à 5 et à $10 \%$, à 33 et à $66 \mathrm{~mm} \mathrm{Hg}$. Celà correspond à une élévation des taux de $\mathrm{Pco}_{2}$ mesurés en transcutanée d'environ $13 \%$ et à une adaptation aux taux des gaz sanguins.

On a comparé les taux déterminés par voie transcutanée avec les données compilées à partir des analyses de sang fotal et avec les valeurs de l'analyse des gaz sanguins effectuée sur le sang artériel ombilical immédiatement après l'accouchement.

L'object de cette étude est de mettre en évidence dans quelle mesure l'évolution du travail influence l'équivalence entre les taux de la $\mathrm{Pco}_{2}$ déterminés par voie transcutanée et par voie sanguine.
Nous avons trouvé un coefficient de correlation, $\mathrm{r}=$ 0,79 et une pente de 1,1 , en comparant les données de la mesure transcutanée (tc $\left.\mathrm{PcO}_{2}\right)$ et celles du sang périphérique ( $\mathrm{pb} \mathrm{Pco}_{2}$ ) en l'absence de bosse séro-sanguine. D'autre part, le coefficient de corrélation s'est abaissé à $\mathrm{r}=0,72$ et la pente à 0,85 en présence d'une bosse séro-sanguine.

L'influence de l'évolution de la tête fœtale dans la filière génitale sur la fiabilité de la mesure transcutanée est également manifeste. Lorsque la tête fotale est au-dessus ou au niveau de détroit moyen, le coefficient de corrélation s'abaisse nettement.

Bien que nos résults montrent une bonne corrélation globale entre les taux de $\mathrm{PCO}_{2}$ mesurés par voie transcutanée et au niveau du sang périphérique, notre analyse montre également l'influence sur la fiabilité à la fois de l'existence d'une bosse séro-sanguine et de l'évolution de la présentation.

Mots-clés: Analyse du sang fœetal, bosse séro-sanguine, évolution du travail, monitoring foetal, $\mathrm{Pco}_{2}$ transcutanée.

\section{Bibliography}

[1] Boenisch, H., E. Saling: The reliability of $\mathrm{pH}-$ values in fetal blood samples. - A study of the second stage. J. Perinat. Med. 4 (1976) 45

[2] Huch, A., R. Huch, H. Schneider, J. Peabody: Experience with transcutaneous $\mathrm{Po}_{2}\left(\mathrm{tc} \mathrm{Po}_{2}\right.$ ) monitoring of mother, fetus and newborn. J. Perinat. Med. 8 (1980) 51
[3] LöFGREN, O.: Continuous transcutaneous oxygen monitoring in the fetus during labor. Crit. Care Med. 9 (1981) 698

[4] LübBers, D. W.: Physiological and clinical significance of $\mathrm{PtcO}_{2}$ and $\mathrm{ptccO}_{2}$ measurements. Crit. Care Med. 9 (1981) 689 
[5] MINDT, W., P. EbERHARD, R. SCHÄFER: Monitoring of $\mathrm{PcO}_{2}$ by skin surface sensors. Biotelemetry Patient Monitg. 9 (1982) 28

[6] Monaco, F., J. C. McQuitty: Transcutaneous measurements of carbon dioxide partial pressure in sick neonates. Crit. Care Med. 9 (1981) 756

[7] Paulick, R.: Der Einfluß der Epidermisdicke auf die transkutane $\mathrm{PO}_{2}$-Messung. $\mathrm{Z}$. Geburtshilfe Perinatol. 186 (1982) 82

[8] Roorh, G., O. FALL, A. Huch, R. Huch: Destribution of observed patterns in fetal transcutaneous oxygen tension. Am. J. Obstet. Gynecol. 140 (1981) 693

[9] SALING, E.: Neues Vorgehen zur Untersuchung des Kindes unter der Geburt. Einführung, Technik und Grundlagen. Arch. Gynaekol. 197 (1962) 108

[10] SALING, E.: Geburtshilfliche Löffel. Z. Geburtshilfe Perinatol. 184 (1980) 310
[11] Schmid, S., K. Langker, J. W. Dudenhausen, E. SALING: Kombinierte Messung von transkutanem $\mathrm{PcO}_{2}$ und $\mathrm{Po}_{2}$ des Feten sub partu. 44. Tagung der Deutschen Gesellschaft für Gynäkologie und Geburtshilfe, München 13. - 17. September 1982

[12] Severinghaus, J. W., M. Stafford, A. F. Bradley: tc $\mathrm{PcO}_{2}$ Electrode Design, Calibration and Temperature Gradient Problems. Acta Anaesthesiol. Scand. 68 (1978) 118

Received May 13, 1983. Accepted January 15, 1984.

Dr. S. Schmidt

Institute of Perinatal Medicine Free University of Berlin Mariendorfer Weg 28 D-1000 Berlin 44, F. R. Germany 